\title{
ESTUDO SOROLÓGICO DE INFECÇÕES EXPERIMENTAIS POR Trypanosoma evansi, EM COBAIAS
}

Teresa Cristina Goulart de OLIVEIRA (1), Roberto SOGAYAR (2) \& Ednir SALATA (2)

\begin{abstract}
RESUMO
Comparamos os métodos de Imunofluorescência Indireta (IFI), Imunodifusāo Radial Dupla e Aglutinação, para a pesquisa de anticorpos em soros, na tripanossomiase experimental por Trypanosoma evansi, em cobaias. Foram obtidas 20 amos tras de soro correspondentes às 4 primeiras semanas de infecção. A IFI foi positiva em apenas 6 animais, com títulos variando de $1: 4$ a 1:16. Os títulos mais altos foram observados na 3a semana pós-infecção. Anticorpos aglutinantes foram observados a partir da 1a semana pós-infecção e, após a $2^{a}$ semana, todos os animais apresentaram reaçäo de aglutinação positiva, com títulos variando de 1:8.000 a 1:250.000. O tratamento dos soros com 2-Mercapto etanol inibiu a reação de aglutinação, sugerindo ser IgM a principal classe dos anticorpos presentes no soro dos animais infectados. Não se constatou a presença de anticorpos precipitantes durante todo o curso da infecção.
\end{abstract}

UNITERMOS: Trypanosoma evansi; Sorologia; Infecçāo experimental.

\section{INTRODUÇÃO}

Infecçōes por Trypanosoma evansi sāo prevalentes em vários países da Ásia, Norte da África e América Latina. O diagnóstico da enfermi dade é relativamente simples em animais com infecções agudas, quando os parasitas estão presentes em grande número no sangue periférico. Entretanto, torna-se mais difícil nas infecçōes crônicas quando as parasitemias sāo baixas e intermitentes. A forma crônica é mais freqüentemente observada em bovinos e búfalos que atuam como reservatórios do parasita (LOSOS, $\left.1980^{8}\right)$.

Conseqüentemente, vários métodos foram estudados afim de demonstrar as reaçōes antígeno-anticorpo nas tripanossomíases por T. evansi, sendo os principais os métodos de Hemaglu- tinaçāo Indireta (GILL, 19644), Difusāo em Gel, Fixaçâo de Complemento (GILL, 1965'5), Aglutinação (JATKAR, $1977^{6}$ ), ELISA (LUCKINS et alii, $1978^{\circ}$ ) e Imunofluorescência Indireta (LUC. KINS et alii, $1979^{10}$ ).

No presente trabalho comparamos os métodos de Imunofluorescência Indireta (IFI), Imunodifusão Radial Dupla e Aglutinaçāo Direta no diagnóstico de infecçōes experimentais de cobaias com $\mathbf{T}$. evansi.

\section{MATERIAL E MÉTODOS}

\section{Animais}

Foram utilizadas 30 cobaias machos com 2 meses de idade, inoculadas por via intraperito-

(1) Prof: Assistente - Dept: de Parasitologia - IB UNESP, Campus de Botucatu. CEP 18610 Botucatu, SP. Brasil.

(2) Prof. Assistente Doutor - Dept: de Parasitologia - IB UNESP, Campus de Botucatu. Botucatu. SP, Brasil. 
OLIVEIRA. T. C. G. de: SOGAYAR, R. \& SALATA, E. - Estudo sorológico de infecçóes experimentais por Trypanosoma evansi, em cobaias. Rev. Inst. Med. trop. Sáo Paulo, 31 (2): 95-99, 1989.

neal com $5 \times 10^{4}$ tripanossomas. A amostra de T. evansi foi fornecida pelo Instituto Biológico de Sáo Paulo.

\section{Obtenção de Soro Imune}

Após a inoculaçāo, semanalmente sorteava se 5 cobaias que eram sangradas por punção car. diaca para obtenção de soro. Desta forma obte ve-se um total de 20 soros, correspondentes às 4 primeiras semanas de infecção. As 10 cobaias restantes morreram no decorrer deste periodo não possibilitando sua utilização. Os soros foram inativados a $56^{\circ} \mathrm{C}$ por 30 minutos e estocados a $-20^{\circ} \mathrm{C}$ até o momento do uso.

\section{Teste de Imunofluorescência Indireta (IFI)}

Conjugado Fluorescente: utilizou-se conjugado fluorescente anti-imunoglobulina (anti-Ig) total de cobaia, produzido em coelho e diluido em PBS e azul de Evans a $0,001 \%$. O conjugado apresentou título de 1:20, diluiçào na qual foi empregado.

Preparo de Lâminas de Antígeno: tripanos somas obtidos de ratos infectados foram lavados em PBS e fixados em formalina a $2 \%$ em salina. Apos 30 minutos os tripanossomas foram lavados por 2 vezes em PBS e distribuídos em lâminas na concentraçào de 10 a 20 parasitas por campo microscópico (400 aumentos).

Reação de Imunofluorescência: os soros foram incubados sobre o material antigénico a $37^{\circ} \mathrm{C}$ por 45 minutos. Em seguida as lâminas foram lavadas 2 vezes por imersāo em PBS durante 10 minutos.

Após nova incubação em presença de conju gado fluorescente, as lâminas foram novamente lavadas por imersão e montadas sob lamínula com auxílio de glicerina tamponada com solução carbonato-bicarbonato $(\mathrm{pH}=8,5)$.

A leitura foi realizada com objetiva $40 \mathrm{X}$, de imersāo, em Microscópio ZEISS munido de lâmpada HBO 200 e condensador de campo escuro.

\section{Teste de Imunodifusāo Radial Dupla}

Utilizou-se a técnica de difusāo em gel de ágar, em placas, segundo OUCHTERLONY $\left(1956^{12}\right)$. Os antígenos foram obtidos através de separaçào dos tripanossomas oriundos de ratos infectados, por passagem em coluna de Dietilaminoetil Celulose (DEAE-celulose) e ulterior ruptura por sonicaçāo. Desta forma foram obtidos antígenos solúveis de $\mathbf{T}$. evansi, nas concen traçōes de 0,$2 ; 1,0 ; 5,0 ; 10$ e $15 \mathrm{mg}$ de proteína $/ \mathrm{ml}$. Além destes, empregou-se soro de ratos com 3 dias de infecção, como possivel fonte de antígenos (BOEHRINGER, 1965²). As reaçōes foram feitas com soro não diluído e diluído em solução salina até 1:128 empregando-se razão 2 . As placas foram incubadas à temperatura ambiente em câmara úmida e as leituras foram feitas após 24,48 e 72 horas.

Além dos soros de cobaias, foram feitas reaçôes com soro de coelho hiperimune, por nós produzido.

\section{Teste de Aglutinação}

Para a reação de aglutinação usou-se como antigeno formas vivas de T. evansi, provenientes de ratos infectados, e separados por centrifugaçāo a $100 \mathrm{~g} / 5 \mathrm{~min}$. A suspensão de tripanossomas era diluída em PBS glicosado a $2 \%$ de forma a se obter uma concentraçāo de $3 \times 10^{6}$ tripanossomas $/ \mathrm{ml}$. Para a reaçâo, realizada em lâminas, utilizou-se $25 \mu$ l desta suspensão e $25 \mu$ l de soro, puro ou diluído. Após 1 hora de incubação a $28^{\circ} \mathrm{C}$ em câmara úmida, procedia-se à leitura em microscópio, empregando objetiva $40 \mathrm{X}$. Os soros que apresentaram titulos aglutinantes foram tratados com soluçāo de 2-mercapto-etanol a $0,2 \mathrm{M}$ (CAMARGO et alii, $1986^{3}$ ), afim de se verificar a classe de imunoglobulina envolvida nesta reaçāo.

\section{RESULTADOS}

\section{Imunofluorescência Indireta}

Dos 20 soros de cobaias examinados, apenas 6 apresentaram reaçāo de IF I positiva, com títulos bastante baixos, variando de $1: 4$ a $1: 16$. Os anticorpos foram primeiramente detectados aos 15 dias pós-infecçāo e os títulos mais altos (1:16) apareceram nos soros de animais com 3 semanas de infecçâo. 
OLIVEIRA, T.C.G. de; SOGAYAR, R. \& SALATA, E. - Estudo sorológico de infecçóes experimentais por Trypanosoma evansi, em cobaias. Rev. Inst. Med. trop. São Paulo, 31 (2): 95 99, 1989.

\section{Imunodifusão Radial Dupla}

Nāo se constatou a presença de anticorpos precipitantes no soro de cobaias, durante todo o curso da infecção, tanto no sistema soro de cobaia-antígeno sonicado, como no sistema soro de cobaia-soro de rato infectado. Para testar a eficiência dos antígenos, a mesma reação foi feita com soro de coelho hiperimunizado contra os dois tipos de antígenos. No sistema soro de coelho hiperimune-antigeno sonicado foi possivel observar precipitaçāo, com antígenos nas concentraçōes protéicas de 10 e $15 \mathrm{mg} / \mathrm{ml}$. Entretanto no segundo sistema (soro de coelho hiperi mune-soro de rato infectado) năo se observou precipitação.

\section{Aglutinaçāo}

Com uma semana de infecção já foi possivel detectar anticorpos aglutinantes no soro de uma cobaia. A partir de 15 dias, todos os animais apresentaram reaçāo positiva com títulos variando de 1:8.000 a 1:250.000. Nesta reação foi possivel observar que os soros só apresentaram aglutinação em diluiçōes acima de 1:16, sendo nega tivas com soro puro e a 1:4, caracterizando o fenômeno de pró-zona. O tratamento dos soros positivos com solução 2-Mercapto-etanol $0,2 \mathrm{M}$ inibiu completamente a reação de aglutinação.

\section{DISCUSSÃO}

O desenvolvimento de métodos sorológicos sensiveis é imprescindível para o diagnóstico das tripanossomíases causadas por T. evansi, uma vez que muitos animais apresentam infecçōes sub-patentes.

Infecções experimentais em cobaias simu lam a forma crônica da infecçāo, pois estas, como os hospedeiros naturais (SEN et alii, $1959^{14}$ ), permanecem infectadas por pelo menos 2 meses antes de morrer (OLIVEIRA et alii ${ }^{11}$ ). Além disso a cobaia é um animal que apresenta boa produ ção de anticorpos, sendo portanto bastante apropriada aos estudos imunológicos com $\mathbf{T}$. evansi (GILL, $1965^{5}$ ).

A IFI nas infecções por T. evansi foi estudada em coelho (GILL, $1965^{5}$; LUCKINS et alii, $1978^{9}$ ) e bovinos (VERMA \& GAUTAM, 1977 ${ }^{15}$ ), com bons resultados. Os resultados por nós obtidos com esta técnica não foram satisfatórios, provavelmente pelo fato de havermos empregado conjugado anti Ig-total de cobaias. Sabendo-se que a resposta imunológica de animais infectados com T. evansi se faz principalmente por anticorpos da classe IgM (LUCKINS et alii, $\left.1978^{9}\right)$, julgamos que o uso de conjugado específico, anti-IgM, deve tornar a técnica mais sensivel.

Anticorpos precipitantes nāo foram detectados no soro de cobaias durante todo o curso da infecção. Entretanto GILL (1965 $)$, descreve a presença destes anticorpos no soro de coelhos. Todavia, este autor empregou soro de coelho imunizado, produzido após repetidas inoculaçōes de parasitas fixados, adicionados de adjuvante e de antígenos solúveis de T. evansi. Utili zando este mesmo tipo de imunizaçāo foi-nos possivel também detectar anticorpos precipitantes no soro de coelhos.

VERMA \& GAUTAM (1977 $\left.{ }^{15}\right)$, mencionam que a imunodifusão em gel apresenta resultados irregulares, com alta freqüencia de falsos negativos. A análise destes fatos sugere-nos que a natureza dos anticorpos seja um dos fatores que deve interferir de forma decisiva no sucesso da reaçâo de imunodifusảo em gel. Desta forma, de vemos considerar as classes de imunoglobulina que poderiam estar envolvidas na reação. IgM é a principal imunoglobulina presente no soro de animais infectados com T. evansi e segundo KLEIN et alii ( $1967^{7}$ ), a IgM 19S difunde-se pouco em gel. Desta forma, como no soro há predominância de IgM 19S esta poderia ser uma das cau sas pelas quais nảo se observa em certos casos a precipitaçāo. Por outro lado, os títulos de IgG caem a niveis indetectáveis após as crises tripanoliticas, provavelmente por formarem imunocomplexos, e posteriormente retornam aos títulos originais (RAADT, $1966^{13}$ ). Por conseguinte, nas formas crônicas da infecçāo, quando os parasitas săo escassos no sangue por prolongados períodos, ou nas imunizações, estes anticorpos (IgG) poderiam ser responsáveis pelas reaçōes positivas nessas ocasióes.

Com relação aos antígenos, BOEHRINGER $\left(1965^{2}\right)$, relata resultados positivos com a técnica de imunodifusāo em gel utilizando como antígeno o soro de ratos com 3 dias de infecçāo con- 
OLIVEIRA, T. C. G. de: SOGAYAR, R. \& SALATA. E. - Estudo sorológico de infecçoes experimentais por Trypanosoma evansi, em cobaias. Rev. Inst. Med. trop. São Paulo, 31 (2): 95-99, 1989.

tra o soro de cavalos. Utilizando esta mesma fonte de antígeno, nâo obtivemos precipitação contra soro de cobaia, bem como contra soro de coelho hiperimunizado. Apesar do referido autor não comentar sobre a natureza do antígeno pro posto, parece-nos ter ele partido da premissa de que antígenos solúveis estariam presentes no soro de ratos com 3 dias de infecção. Entretanto, ALLSOP et alii (1971 $)$ mostraram evidências de que antígenos solúveis de tripanossomas do sub grupo brucei, não se apresentam "in vivo", ocorrendo somente "in vitro" por desintegraçāo dos parasitas. Como nāo nos foi possível encontrar na literatura outra referência sobre o emprego de soro de animal infectado como fonte de antígeno para o diagnóstico desta tripanossomíase, julgamos que maiores estudos devem ser feitos para que se possa concluir a questāo.

A reação de aglutinação foi a técnica mais sensivel no diagnóstico da infecção por T. evansi em cobaias, pois os resultados apareceram pre cocemente e os títulos foram bastante altos. Estes resultados são semelhantes aos obtidos por GILL (1965 ), confirmando ser a aglutinação uma reaçāo bastante sensível.

O tratamento dos soros com 2-Mercapto-e tanol, inibiu completamente a reaçāo de aglutinação, sugerindo, portanto, ser IgM a principal classe de imunoglobulina presente no soro de cobaias infectadas com T. evansi. Segundo LUCKINS et alii $\left(1978^{9}\right)$ os niveis de IgM aumentam de 5 a 20 vezes em relação aos níveis normais, nos animais infectados com $\mathbf{T}$. evansi.

\section{SUMMARY}

Studies on the serological diagnosis of experimental infection with Trypanosoma evansi in guinea-pigs.

Sera of 20 guinea-pigs experimentally infected with Trypanosoma evansi were obtained in order to compare the efficacy of gel diffusion, indirect immunofluorescence and agglutination tests, to detect antibodies to T. evansi. The fluorescent antibody test was positive in six ( 6 ) animals and the antibody titres were very low $1: 4$ to $1: 16$ ). The agglutination test detected trypanosomal antibodies in sera one (1) week after infection. After two (2) weeks all animals were positive with high titres (1:8.000 to 1:250.000). Agglutination was inhibited when sera were treated with 2-Mercapto-etanol. This fact suggests that IgM is the principal class of antibodies in sera of infected guinea-pigs. Precipitating antibodies were not detected during the course of infection.

\section{REFERENNCIAS BIBLIOGRÁFICAS}

1. ALLSOPP. B. A.; MJOGU, A. R. \& HUMPHRYES, K. C. - Nature and location of Trypanosoma brucei subgroup exoantigen and its relationship to 4 S antigen. Exp. Parasit., 29: 271.284, 1971

2. BOEHRINGER, E. G. - La doble difusion en agar en el diagnostico del "Mal de Caderas" (T. equinum). Rev. Med. vet. (B. Aires), 46: 425-431, 1965.

3. CAMARGO, M. E.; FERREIRA. A. W.: ROCCA, A. \& BE LEM, Z. R. - Um teste prático para a sorologia da toxo. plasmose: o teste de hemaglutinaçào. Estudo compara tivo com os testes de imunofluorescência e imunoenzimático de captura de IgM. Rev. bras. Pat. clín., 22: 196-201. 1986 .

4. GILL, B. S. - A procedure for the indirect haemaggluti. nation test for the study of experimentally Trypanosoma evansi infections. Ann. trop. Med. Parasit., 58: 473.480 , 1964.

5. GILL, B. S. - Studies on the serological diagnosis of Trypanosoma evansi. J. comp. Path., 75: 175-183, 1965.

6. JATKAR, P. R.; RAO, P. V. \& SINGH, M. - Diagnosis of Surra: capillary agglutination test. Indian vet. J., 54: 795-797, 1977.

7. KLEIN, F.: MATTERN, P.; RADEMA, H. \& VANZEWT, T. L. - Slowly sedimenting serum components reacting with anti-IgM sera. Immunology, 13: 641-647, 1967.

8. LOSOS, G. J. - Diseases caused by Trypanosoma evansi. A review. Vet. Res. Comm., 4: 165-181, 1980.

9. LUCKINS, A. G.: GRAY, A. R. \& RAE, P. - Comparison of the diagnostic value of serum immunoglobulin levels, an enzime-linked immunosorbent assay and a fluorescent antibody test in experimental infections with Trypanosoma evansi in rabbits. Ann. trop. Med. Parasit., 72: 429. 441,1978 .

10. LUCKINS, A. G.; BOID, R.; RAE, P.; MAHMOUD, M. M.; EL MAZIK, K. H. \& GRAY, A. R. - Serodiagnosis of infection with Trypanosoma evansi in camels in the Sudan. Trop. Anim. HIth. Prod., 11: 1-12, 1979.

11. OLIVEIRA, T. C. G.; MENEGUIN, J. M. \& PEREIRA, E. A. - Comportamento do Trypanosoma evansi $(=\mathrm{T}$. equinum) em animais de laboratório. Arq. bras. Med. vet. Zoct., (No prelo) 
OLIVEIRA, T. C. G. de; SOGAYAR, R. \& SALA TA, E. - Estudo sorológico de infecçôes experimentais por Trypanosoma evansi, em cobaias. Rev. Inst. Med. trop. São Paulo, 31 (2): 95 99, 1989.

12. OUCHTERLONY, O. - Diffusion-in-gel methods for immunological analysis. Progr. Allergy, 5: 1, 1958.

13. RAADT, P. de - Immunity and antigenic variation: clini. cal observations suggestive of immune phenomena in African trypanosomiasis. In: TRYPANOSOMIASIS AND LEISHMANIASIS WITH SPECIAL REFERENCE TO CHAGAS' DISEASE. Amsterdam, Elsevier, 1974. p. 199-216. (Ciba Foundation Symposium 20, new series).

14. SEN, H. G.; DUTTA, B. N. \& RAY, H. N. - Biochemical changes in experimentally induced Trypanosoma evansi infection in rabbits and guinea-pigs. Indian $\mathbf{J}$. vet. Sci. 29: $118-123,1959$

15. VERMA, B. B. \& GAUTAM, O.P. - Serological diagnosis of experimental bovine surra (Trypanosoma evansi) infection. A comparison of passive haemagglutination, gel dif fusion and indirect fluorescent antibody tests. Indian vet. J., 59: 809-813, 1977.

Recebido para publicação em 4/7/1988 